Review article

\title{
Oxidative stress generation by microcystins in aquatic animals: Why and how
}

\author{
L.L. Amado, J.M. Monserrat* \\ Curso de Pós-graduação em Ciências Fisiológicas - Fisiologia Animal Comparada, Cx. P. 474, CEP 96.201-900, Rio Grande, RS, Brazil \\ Instituto de Ciências Biológicas, Universidade Federal do Rio Grande - FURG, Cx. P. 474, CEP 96.201-900, Rio Grande, RS, Brazil
}

\section{A R T I C L E I N F O}

\section{Article history:}

Received 15 July 2009

Accepted 27 October 2009

Available online 5 December 2009

\section{Keywords:}

Microcystins toxicity

Aquatic organisms

Oxidative stress

Hyperphosphorylation

Phosphorylation of antioxidant enzymes

\begin{abstract}
A B S T R A C T
Microcystins (MICs) are potent toxins produced worldwide by cyanobacteria during bloom events. Phosphatases inhibition is a well recognized effect of this kind of toxins as well as oxidative stress. However, it is not fully understood why and how MICs exposure can lead to an excessive formation of reactive oxygen species (ROS) that culminate in oxidative damage. Some evidences suggest a close connection between cellular hyperphosphorylation state and oxidative stress generation induced by MICs exposure. It is shown, based on literature data, that MICs incorporation per se can be the first event that triggers glutathione depletion and the consequent increase in ROS concentration. Also, literature data suggest that hyperphosphorylated cellular environment induced by MICs exposure can modulate antioxidant enzymes, contributing to the generation of oxidative damage. This review summarizes information on MICs toxicity in aquatic animals, focusing on mechanistic aspects, and rise questions that in our opinion needs to be further investigated.
\end{abstract}

(c) 2009 Elsevier Ltd. All rights reserved.

\section{Contents}

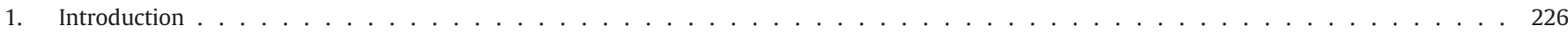

2. Why microcystins induce oxidative stress in aquatic organisms? . . . . . . . . . . . . . . . . . . . . . . . . . . 227

3. How microcystins induce oxidative stress in aquatic organisms ? . . . . . . . . . . . . . . . . . . . . . . . . . . . . . . 231

4. Chemoprevention strategies against oxidative stress generated by microcystins . . . . . . . . . . . . . . . . . . . . . . . . . 232

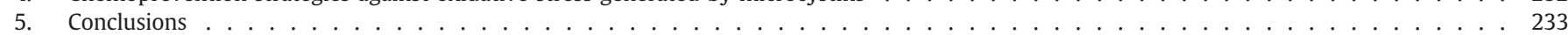

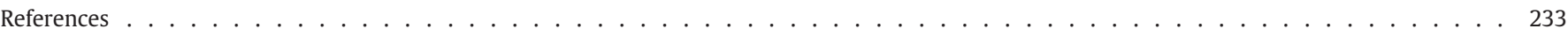

\section{Introduction}

Anthropogenic activities along with deficient water management have led to the enhancement of eutrophication in water bodies all over the world (Svrcek and Smith, 2004; Carmichael, 2007). Eutrophication processes plus specific environmental conditions such as high temperature and $\mathrm{pH}$ values, low turbulence and high nutrients input, can lead to cyanobacterial blooms, which are characterized by excessive proliferation of cyanobacterial cells (de Figueiredo et al., 2004).

Cyanobacteria (blue-green algae) are capable of producing a wide range of toxins including hepatotoxins, neurotoxins, cytotoxins, dermatoxins and irritant toxins (lipopolysaccharides) (Wiegand and

\footnotetext{
* Corresponding author. Instituto de Ciências Biológicas (ICB), Universidade Federal do Rio Grande - FURG, Cx. P. 474, CEP 96.201-900, Rio Grande, RS, Brazil. Tel.: +55 53 32336856.

E-mail address: josemmonserrat@pesquisador.cnpq.br (J.M. Monserrat).
}

Pflugmacher, 2005). Globally, the most frequently found cyanotoxins in fresh and brackish water are the cyclic peptide toxins of microcystins (MICs) family and nodularins (Chorus and Bartram, 1999). Microcystins (MICs) are potent hepatotoxins produced by a number of planktonic cyanobacteria genera, such as Anabaena, Anabaenopsis, Nostoc, Planktothrix and Microcystis (Chorus and Bartram, 1999). There are more than 75 isoforms of MICs varying by degree of methylation, hydroxylation, epimerization, peptide sequence and toxicity. Besides this great variability, MICs collectively may be described as monocyclic heptapeptides containing both $\mathrm{D}-$ and $\mathrm{L}-$ amino acids plus $\mathrm{N}$-methyldehydroalanine (Mdha) and a unique $\beta$ amino acid side-group, 3-amino-9-methoxy-2-6,8-trymethyl,10-phenyldeca-4,6-dienoic acid (Adda) (Svrcek and Smith, 2004).

The concentration of dissolved toxin in the environment varies from traces up to $1800 \mu \mathrm{g} / \mathrm{L}$ or higher, immediately after the collapse of a highly toxic bloom (Chorus and Bartram, 1999; Svrcek and Smith, 2004). The intact cells as well as the toxins released after cellular lysis can be responsible for the toxic effects observed in many organisms, 
from microalgae to mammals (de Figueiredo et al., 2004; Jos et al., 2005).

Aquatic organisms are exposed to MICs by several different routes. They can come into direct contact with toxins after the senescence and lysis of cyanobacterial cells. In addition some phytoplanktivorous and omnivorous species can ingest cyanobacterial cells as food ( $\mathrm{Li}$ et al., 2004; Xie et al., 2004). It is also important to consider that in natural environments, surface aggregations of some cyanobacteria (complex cyanobacterial samples) may accumulate to scum with high cell density and toxin concentrations, thus increasing the potential toxicity to aquatic animals in direct contact with it (Chorus and Bartram, 1999). The fact that MICs have been found to accumulate in species of zooplankton (Mohamed, 2001), mussels (Eriksson et al. 1989; Amorim and Vasconcelos 1999), crustaceans (Chen and Xie, 2005), marine biota consumed as "seafood" (Ibelings and Chorus, 2007), several fish species (Soares et al., 2004; Cazenave et al., 2005; Chen et al., 2006a) and other vertebrates (Chen et al., 2009) indicates that another route of exposure to the toxin, both for aquatic and terrestrial species, including humans, is the consumption of aquatic organisms which had previously accumulated microcystin in their tissues (Zhang et al., 2009). For example, MICs content in the muscle of Nile tilapia exposed to the toxin through food exceeded the upper limit of the tolerable daily intake (TDI) suggested by the WHO $(0.04 \mu \mathrm{g} / \mathrm{kg}$ body weight/day), suggesting that Nile tilapia fed on toxic cyanobacteria is not suitable for human consumption (Zhao et al., 2006).

Due to its high molecular weight (varying from 900 to $1100 \mathrm{Da}$ ), MICs are unable to easily penetrate biological membranes and bioconcentrate (Svrcek and Smith, 2004). However, some kinds of cells express specific membrane transporters that enable toxin accumulation.

Consequences of MICs intoxication in mammals include disruption of liver cytoskeleton, apoptosis, necrosis and internal hemorrhage in liver that may lead to death by hemorrhagic shock in acute intoxication (Dawson, 1998). MICs chronic ingestion can cause increased liver weight, hepato-histological damage (Heinze, 1999), liver cancer (Hu et al., 2008; Hernández et al., 2009; Li et al., 2009) and kidney damage (Milutinovi et al., 2003). In juvenile and adult fish species, analogous, but not identical effects were observed when they were exposed to purified MICs or cyanobacterial material (Fischer et al., 2000). Studies with different fish species have shown that chronic MICs exposure mainly affects growth (Bury et al., 1995; Kamjunke et al., 2002), blood indices (Li et al., 2004, 2008a; Qiu et al., 2009), ionic regulation (Gaete et al., 1994; Bury et al., 1996) histopathology (Fischer and Dietrich, 2000a; Fischer et al., 2000), heart rate (Best et al., 2001), locomotor activity and behaviour (Baganz et al., 2004; Cazenave et al., 2008). Early life stages are more susceptible to the toxin than adult fish, because of the thinner epithelial layer combined with a relative large body surface, high metabolic rate and limited mobility. Several laboratory and field studies describe the effects induced by chronic MICs exposure in early life stages of fish as interferences with developmental processes and organ functions, which can decrease the survival rate of enough individuals to effectively affect at the population level (Malbrouck and Kestemont, 2006).

In aquatic invertebrate species the effects of MICs exposure are less well known (Martins and Vasconcelos, 2009). Sessile species may be the most obvious group of organisms threatened by the presence of toxic cyanobacteria. In fact, some studies have demonstrated altered larvae survival and development, changes on feeding behaviour and energy balance in a mussel species (Dreissena polymorpha) feeding on phytoplankton (Pires et al., 2003). However, insensitivity to MICs has also been reported in bivalves, where expulsion via pseudo-faeces has been described as a primary defense mechanism. For example, Dreissena polymorpha produces large quantities of mucous, called 'pseudodiarrhoea', periodically expelled through the pedal gape by shell valve adduction when exposed to highly toxic strains of cyanobacteria (Juhel et al., 2006). Contardo-Jara et al. (2008) demonstrated that exposure of $D$. polymorpha to MIC-LR was related to an immediate increase in P-glycoprotein (P-gp) activity, suggesting multi-xenobiotic-resistance as a possible explanation for the insensitivity of bivalves towards cyanobacterial toxins.

At the molecular level, the classical mechanism of MIC toxicity is the irreversible inhibition of serine/threonine protein phosphatases PP1 and PP2A, an effect described in zooplankton (DeMott and Dhawale, 1995), amphibians (Fischer and Dietrich, 2000a), fish (Fischer and Dietrich, 2000b; Fischer et al., 2000) and mammals (Chen et al. 2006b). However, several recent reports have argued that oxidative stress is also a toxicological consequence of the exposure to MICs in different organisms.

Oxidative stress is classically defined as a disturbance in the prooxidant/antioxidant balance in favor of the former, leading to potential molecular damage (Halliwell and Gutteridge, 2007). However, the major cellular thiol/disulfide systems, including GSH/ GSSG, thioredoxin-1 (-SH2 $/-\mathrm{SS}-)$, and Cys/CySS, are not in redox equilibrium and respond differently to chemical toxicants and physiologic stimuli. Thus, from a mechanistic standpoint, oxidative stress may be better defined as a disruption of redox signaling and control (Jones, 2006). So, the aim of the present review is to make a compilation of recent information on MICs toxicity, with regard mainly to aquatic animals. Also, some topics that we believe need to be investigated are highlighted.

\section{Why microcystins induce oxidative stress in aquatic organisms?}

In the last years, as shown in Table 1 , several evidences indicate that MICs can alter the antioxidant system and/or induce oxidative stress in diverse aquatic species and organs, a fact that prompt us to analyze and review such important toxicological issue. MICs uptake has been related to the production of reactive oxygen species (Ding et al., 2000a, 2001; Li et al., 2003), leading to an increase in lipid peroxidation (Pinho et al., 2005; Jos et al., 2005; Prieto et al., 2007), DNA damage (Zegura et al., 2003, 2008; Votto et al., 2007), DNAprotein crosslink (Leão et al., 2008), mitochondrial damage (Ding and Ong, 2003) and alteration of the antioxidant defense system (Vinagre et al., 2003; Pinho et al., 2005; Cazenave et al., 2006a,b; Prieto et al., 2007; Amado et al., 2009). However, the causes and the mechanisms involved in these responses have been analyzed in lesser depth.

A cyanobacterial bloom can promote oxidative stress simply by generating hyperoxia/anoxia cycles through photosynthetic and respiratory processes, as previously observed under a cyanobacterial bloom dominated by the genera Microcystis and Anabaena, among others (Seki et al., 1980). A cycle of low/high oxygen levels in the water column was suggested by Rosa et al. (2005) to explain the extremely high levels of lipid peroxidation in the estuarine worm, Laeonereis acuta (Nereididae) collected under a bloom event dominated by cyanobacteria genera such as Anabaena, Aphanocapsa, Merismopedia and Snowella. Hypoxia/hyperoxia cycles occurring in nature, resemble the ischemic/reperfusion process. After a reduction of oxygen flow (ischemia), the return of oxygen in the reperfusion causes an increase in the production of reactive oxygen species (ROS), leading to oxidation of cellular components including proteins, membrane lipids and DNA. The electron carriers of the mitochondrial respiratory chain are reduced during ischemia, whereas immediate re-oxygenation of these carriers takes place after the reperfusion, leading to oxyradical overproduction (Halliwell and Gutteridge, 2007).

In vitro studies, however, have shown that the ROS production is also a metabolic response to MICs exposure and not only an effect analog to ischemia/reperfusion process. Ding and Ong (2003) reported elevated ROS levels in rat hepatocytes just $5 \mathrm{~min}$ after exposing them to $1 \mu \mathrm{M}$ 
Table 1

Some evidences of oxidative stress or alteration in antioxidant system of aquatic animals exposed to microcystins.

\begin{tabular}{|c|c|c|c|c|c|c|}
\hline Species & Organ & Exposure & $\begin{array}{l}\text { Antioxidant } \\
\text { response analyzed }\end{array}$ & $\begin{array}{l}\text { Oxidative } \\
\text { stress } \\
\text { parameters } \\
\text { analyzed }\end{array}$ & Main observed effects & Reference \\
\hline Laeonereis acuta $(\mathrm{P})$ & Whole animal & $\begin{array}{l}\text { Immersion in Microcystis aeruginosa } \\
\text { extract }(\sim 2 \mu \mathrm{g} \mathrm{MIC} / \mathrm{mL}) \text { during } 48 \mathrm{~h}\end{array}$ & $\begin{array}{l}\text { CAT, GST and GR } \\
\text { activities }\end{array}$ & LPO & $\begin{array}{l}\text { Lower CAT activity and no alteration on GST } \\
\text { activity; higher LPO levels and DNA-protein } \\
\text { cross-links content }\end{array}$ & $\begin{array}{l}\text { Leão et al. } \\
\text { (2008) }\end{array}$ \\
\hline $\begin{array}{l}\text { Chasmagnathus } \\
\text { granulatus }^{\mathrm{a}}(\mathrm{C})\end{array}$ & $\begin{array}{l}\text { Gills (anterior } \\
\text { and posterior) }\end{array}$ & $\begin{array}{l}\text { Injected with Microcystis aeruginosa } \\
\text { extract }(39.2 \mu \mathrm{MIC} / \mathrm{L}) \text { during } 48 \mathrm{~h}\end{array}$ & $\begin{array}{l}\text { Total antioxidant } \\
\text { capacity (TOSC } \\
\text { assay }{ }^{\text {) }} \text { and GST } \\
\text { activity. }\end{array}$ & LPO & Higher TOSC and GST in posterior gills. & $\begin{array}{l}\text { Vinagre } \\
\text { et al. } \\
\text { (2003) }\end{array}$ \\
\hline $\begin{array}{l}\text { Chasmagnathus } \\
\text { granulatus }^{\mathrm{a}}(\mathrm{C})\end{array}$ & Hepatopancreas & $\begin{array}{l}\text { Injected with Microcystis aeruginosa } \\
\text { extract }(17.6 \mu \mathrm{M} \mathrm{MIC} / \mathrm{L}) \text { during } 72 \mathrm{~h} \\
\text { and one week of exposure }\end{array}$ & $\begin{array}{l}\text { CAT, SOD and GST } \\
\text { activities }\end{array}$ & LPO & $\begin{array}{l}\text { Higher CAT and GST activities in crabs exposed } \\
\text { for } 7 \text { days. No effect on SOD activity and LPO } \\
\text { levels }\end{array}$ & $\begin{array}{l}\text { Pinho et } \\
\text { al. (2003) }\end{array}$ \\
\hline $\begin{array}{l}\text { Chasmagnathus } \\
\text { granulatus }^{\mathrm{a}}(\mathrm{C})\end{array}$ & Hepatopancreas & $\begin{array}{l}\text { Forced ingestion ( 1 and } 5 \mu \mathrm{g} \mathrm{MIC} / \mathrm{kg}) \\
\text { during } 168 \mathrm{~h}\end{array}$ & $\begin{array}{l}\text { CAT, GST and SOD } \\
\text { activities }\end{array}$ & $\begin{array}{l}\text { LPO and } \\
\text { protein } \\
\text { carbonyl } \\
\text { groups }\end{array}$ & $\begin{array}{l}\text { Biphasic alteration of CAT; Augmented GST } \\
\text { activity; Higher LPO levels }\end{array}$ & $\begin{array}{l}\text { Pinho et } \\
\text { al. (2005) }\end{array}$ \\
\hline $\begin{array}{l}\text { Chasmagnathus } \\
\text { granulatus }^{\mathrm{a}}(\mathrm{C})\end{array}$ & Hepatopancreas & $\begin{array}{l}\text { Gavage with Microcystis aeruginosa } \\
\text { extracts }(34,172,860 \mu \mathrm{MIC} / \mathrm{kg}) \\
\text { during } 6,12 \text { and } 72 \mathrm{~h} .\end{array}$ & GST activity & LPO & $\begin{array}{l}\text { Higher GST activity in crabs exposed to } 860 \mu \mathrm{g} \\
\mathrm{MIC} / \mathrm{kg} \text { for } 12 \mathrm{~h} \\
\text { Higher LPO levels in crabs exposed to all doses } \\
\text { after } 72 \mathrm{~h} \text { of exposure }\end{array}$ & $\begin{array}{l}\text { Dewes et } \\
\text { al. (2006) }\end{array}$ \\
\hline Danio rerio $(\mathrm{F})$ & Fish embryos & $\begin{array}{l}\text { Immersion in REKO medium } \\
\text { containing } 0.1,0.5,1,2 \text { and } 5 \mu \mathrm{g} \text { MIC- } \\
\text { LR/L over ontogenetic development } \\
\text { and after hatch ( } 3 \text { and } 5 \text { days) }\end{array}$ & $\begin{array}{l}\text { sGST, mGST and } \\
\text { GPx activity }\end{array}$ & None & $\begin{array}{l}\text { Dose dependent increase in sGST and mGST } \\
\text { activity over ontogenetic development (from } \\
0.1 \text { to } 2 \mu \text { g MIC-LR/L). The higher dose } \\
\text { suppressed soluble GST activity. GPx increased } \\
\text { in } 0.5 \mu \mathrm{g} \text { MIC-LR/L exposure dose }\end{array}$ & $\begin{array}{l}\text { Wiegand } \\
\text { et al. } \\
\text { (1999) }\end{array}$ \\
\hline $\begin{array}{l}\text { Hypophthalmichthys } \\
\text { molitrix (F) }\end{array}$ & Hepatopancreas & $\begin{array}{l}\text { Immersion in a cyanobacterial bloom } \\
\text { (Microcystis ichthyoblabe } 60 \% \text { and } M \text {. } \\
\text { aeruginosa } 40 \%, 4-116 \times 10^{6} \text { cells } / \mathrm{mL}\end{array}$ & GSH & LPO & Higher GSH and no LPO effect & $\begin{array}{l}\text { Bláha et } \\
\text { al. (2004) }\end{array}$ \\
\hline Oreochromis sp (F) & $\begin{array}{l}\text { Liver, kidney } \\
\text { and gills }\end{array}$ & $\begin{array}{l}\text { Cyanobacterial cells mixed with a } \\
\text { commercial fish food or crushed into a } \\
\text { commercial fish food through } 14 \text { and } \\
21 \text { days. }\end{array}$ & $\begin{array}{l}\text { SOD, CAT, GPx, GR } \\
\text { activities }\end{array}$ & LPO & $\begin{array}{l}\text { In general, antioxidant enzymes and LPO were } \\
\text { increased after } 21 \text { days of exposure to crushed } \\
\text { food in almost all organs, but liver was the } \\
\text { most affected. }\end{array}$ & $\begin{array}{l}\text { Jos et al. } \\
(2005)\end{array}$ \\
\hline $\begin{array}{l}\text { Misgurnus mizoleps } \\
\text { (F) }\end{array}$ & Liver & $\begin{array}{l}\text { Orally exposed to } 75 \mathrm{mg} \text { of dry cells/kg } \\
\text { body weight (equal to } 10 \mu \mathrm{g} \text { MIC-RR/ } \\
\mathrm{kg} \text { body mass), for } 28 \text { days }\end{array}$ & $\begin{array}{l}\text { SOD, CAT, GPx } \\
\text { activities }\end{array}$ & LPO & $\begin{array}{l}\text { Activity of antioxidant enzymes was increased } \\
\text { and LPO remained stable. }\end{array}$ & $\begin{array}{l}\text { Li et al. } \\
(2005)\end{array}$ \\
\hline Danio rerio $(\mathrm{F})$ & Fish embryos & $\begin{array}{l}\text { Immersion in REKO medium with } \\
25 \mu \mathrm{g} \text { MIC-RR/L or } 25 \mu \mathrm{g} \text { MIC-LF/L } \\
\text { during } 24 \mathrm{~h}\end{array}$ & $\begin{array}{l}\text { sGST, mGST, CAT, } \\
\text { POD, GPX, GR }\end{array}$ & None & $\begin{array}{l}\text { Higher SGST, mGST and CAT activity; no effect } \\
\text { in the other analyzed enzymes }\end{array}$ & $\begin{array}{l}\text { Cazenave } \\
\text { et al. } \\
(2006 a)\end{array}$ \\
\hline $\begin{array}{l}\text { Corydoras paleatus } \\
\text { (F) }\end{array}$ & $\begin{array}{l}\text { Liver, gill, } \\
\text { intestine and } \\
\text { brain }\end{array}$ & $\begin{array}{l}\text { MIC-RR dissolved in water (up to } 1 \mu \mathrm{g} / \\
\mathrm{L} \text { ) during } 24 \mathrm{~h}\end{array}$ & $\begin{array}{l}\text { CAT, GPx, GR, GST, } \\
\text { POD activities }\end{array}$ & TBARS & $\begin{array}{l}\text { Decreased GST activity in all organs; the other } \\
\text { antioxidant enzymes augmented in liver; } \\
\text { higher LPO levels in brain }\end{array}$ & $\begin{array}{l}\text { Cazenave } \\
\text { et al. } \\
(2006 \mathrm{~b})\end{array}$ \\
\hline Oreochromis sp (F) & $\begin{array}{l}\text { Liver, kidney } \\
\text { and gill }\end{array}$ & $\begin{array}{l}\text { I.p. injection of a single dose of } 500 \mu \mathrm{g} \\
\text { MIC-LR/kg or } 500 \mu \mathrm{g} \text { MIC-RR/kg and } \\
\text { killed after } 7 \text { days. }\end{array}$ & SOD, CAT, GPX; GR & LPO & $\begin{array}{l}\text { In general, antioxidant enzymes, mainly SOD } \\
\text { and CAT, and LPO levels were increased }\end{array}$ & $\begin{array}{l}\text { Prieto et } \\
\text { al. (2006) }\end{array}$ \\
\hline $\begin{array}{l}\text { Oreochromis } \\
\text { niloticus (F) }\end{array}$ & $\begin{array}{l}\text { Liver, kidney } \\
\text { and gills }\end{array}$ & $\begin{array}{l}\text { Food pellets with } 1350 \mu \mathrm{g} / \mathrm{g} \text { of pellet } \\
\text { during } 24 \mathrm{~h}\end{array}$ & $\begin{array}{l}\text { CAT, GPx, GR and } \\
\text { SOD activities }\end{array}$ & $\begin{array}{l}\text { LPO and } \\
\text { protein } \\
\text { carbonyl } \\
\text { groups }\end{array}$ & $\begin{array}{l}\text { In general, a decreased activity of antioxidant } \\
\text { enzymes; higher LPO levels in all organs. } \\
\text { Higher protein oxidation in liver. }\end{array}$ & $\begin{array}{l}\text { Prieto et } \\
\text { al. (2007) }\end{array}$ \\
\hline Tinca tinca $(\mathrm{F})$ & $\begin{array}{l}\text { Liver and } \\
\text { kidney }\end{array}$ & $\begin{array}{l}\text { Orally exposed to cyanobacterial cells } \\
\text { dosing } 5,11,25 \text { and } 55 \mathrm{mg} \text { MC-LR/fish } \\
\text { mixed with the food }\end{array}$ & $\begin{array}{l}\text { SOD, CAT, GSH, } \\
\text { GSH/GSSG }\end{array}$ & $\begin{array}{l}\text { LPO and } \\
\text { protein } \\
\text { carbonyl } \\
\text { groups }\end{array}$ & $\begin{array}{l}\text { SOD activity decreased in a dose dependent } \\
\text { manner in liver and kidney; decrease in CAT } \\
\text { activity in the liver in the two higher doses and } \\
\text { no effect in CAT activity in kidney; no effect on } \\
\text { GSH and GSH/GSSG levels; LPO increased in } \\
\text { the two higher doses; no effect in protein } \\
\text { oxidation }\end{array}$ & $\begin{array}{l}\text { Atencio } \\
\text { et al. } \\
\text { (2008) }\end{array}$ \\
\hline Carassius auratus (F) & $\begin{array}{l}\text { Liver, kidney } \\
\text { and intestine }\end{array}$ & $\begin{array}{l}\text { One injection ( } 50 \text { and } 200 \mu \mathrm{g} \mathrm{MIC} / \mathrm{kg} \text { ) } \\
\text { and then followed up to } 168 \mathrm{~h}\end{array}$ & $\begin{array}{l}\text { Expression of } \\
\text { several GST genes }\end{array}$ & None & $\begin{array}{l}\text { In general decreased transcription of several } \\
\text { GST isoforms (including } \alpha, \pi \text { and } \theta \text { ) }\end{array}$ & $\begin{array}{l}\text { Li et al. } \\
(2008 \mathrm{a}, \mathrm{b})\end{array}$ \\
\hline $\begin{array}{l}\text { Jenynsia } \\
\text { multidentata (F) }\end{array}$ & Liver and brain & $\begin{array}{l}\text { Food pellets with MIC-RR (up to } 1 \mu \mathrm{g} / \mathrm{g} \\
\text { of pellet) and analyzed during } 24 \mathrm{~h}\end{array}$ & GST activity & None & Higher GST activity at the highest dose & $\begin{array}{l}\text { Cazenave } \\
\text { et al. } \\
(2008)\end{array}$ \\
\hline $\begin{array}{l}\text { Jenynsia } \\
\text { multidentata }(\mathrm{F})\end{array}$ & $\begin{array}{l}\text { Liver, brain, } \\
\text { gills and muscle }\end{array}$ & $\begin{array}{l}\text { Microcystis aeruginosa cells (RST9501) } \\
\text { extracts dissolved in water to reach } 5 \\
\text { and } 100 \mu \mathrm{g} / \mathrm{L} \text { toxin }\end{array}$ & $\begin{array}{l}\text { Total antioxidant } \\
\text { competence against } \\
\text { peroxyl radicals } \\
\text { (ANCOMROS) }\end{array}$ & $\begin{array}{l}\text { Protein } \\
\text { oxidation } \\
\text { (carbonyl } \\
\text { groups) }\end{array}$ & $\begin{array}{l}\text { Increased ANCOMROS in liver and decreased } \\
\text { antioxidant capacity in brain and gills. There } \\
\text { was no protein oxidation in liver. }\end{array}$ & $\begin{array}{l}\text { Amado et } \\
\text { al. (2009) }\end{array}$ \\
\hline
\end{tabular}

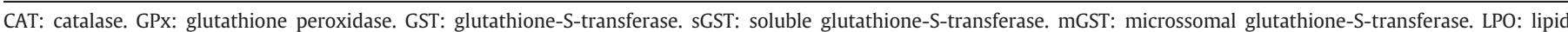

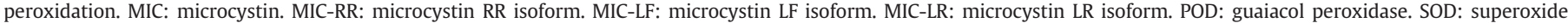
dismutase. TOSC: total oxyradical scavenging capacity. P, C and F refer to polychaeta, crustacean and fish species, respectively.

a Now cited as Neohelice granulata.

b Winston et al. (1998).

MIC-LR. High levels of ROS generation were also reported for fish hepatocytes and lymphocytes (Li et al., 2003; Zhang et al., 2007), after 30 and 90 min of MIC exposure, respectively.
Along with the increased level of ROS production, several studies have evidenced the alteration in cytosolic glutathione (GSH) concentration due to MICs exposure. GSH is the most abundant 
non-protein thiol, being found at the milimolar range in most cells, playing a key role as antioxidant (Dickinson and Forman, 2002; Maher, 2005). A biphasic response in terms of glutathione (GSH) levels has been reported by Ding et al. (2000b) in rat hepatocytes during exposure to a microcystic cyanobacteria extract $(125 \mu \mathrm{g} / \mathrm{mL}$ lyophilized algae cells). The authors considered that the initial increase of intracellular GSH is probably because its conjugation with microcystin, as previously shown by Pflugmacher et al. (1998), triggering the synthesis of new GSH. The subsequent GSH depletion, was considered to be related to cell membrane damage and consequent GSH efflux (Ding et al., 2000b). In contrast, Runnegar et al. (1987) and Li et al. (2003) described only a decrease in GSH concentration, 10 and 15 min after rat and fish hepatocytes exposure to the toxin, respectively. In both studies purified MIC-LR was used and could explain the different response observed by Ding et al. (2000b) as they used cyanobacteria extract. It has been manifested already that other components of cyanobacteria cells than the toxin, such as lipopolysaccharides, can have influence in toxic responses (Best et al., 2002).

MICs were suggested to disrupt the mitochondrial electron transport chain (ETC), thus favoring ROS generation (Ding et al., 2002). However, high ROS levels were observed prior to the landmark effects of dysfunctional mitochondria, including membrane potential depolarization and mitochondrial permeability transition (MPT) (Ding et al., 2000a; Ding and Ong, 2003). Mitochondria are not only the main site of production of ROS, but also the main target of such toxic molecules, so the maintenance of its antioxidant capacity is vital for cell integrity (Aon et al., 2007). It has been attested already that mitochondria do not have the enzymatic pool associated with GSH synthesis and that mitochondrial GSH is of cytoplasmatic origin (Meister, 1995). So depletion of cytosol GSH could reflect in a decreased GSH concentration inside mitochondria, a situation that favors the described increase in ROS production and ETC disruption induced by MICs. We also have to consider that mitochondrial permeability transition pore (PTP) is under redox control (Aon et al.,
2007). Oxidative stress through oxidation of intracellular GSH and other critical sulfhydryl groups favors the PTP opening (Chernyak, 1997), which leads to membrane potential depolarization and mitochondrial permeability transition (MPT). As mentioned above, these are the effects described in hepatocytes exposed to MICs. Mikhailov et al. (2003) showed that MIC-LR can bind to the beta subunit of ATP-synthase, what can contribute to the intensification of the mitochondrial membrane depolarization, disruption of ETC and ROS generation. Mitochondrial membrane depolarization leads to the release of cytochrome $c$, signaling to apoptosis, a microcystin effect that has been shown in several studies using cell lines from different organisms, including fish (Ding et al., 2002; Zhang et al., 2006, 2007, 2008).

In the context of the GSH biphasic response or depletion after MICs exposure, other possible consequences of MICs and ATP-synthase interaction can be postulated, since any ATP synthesis impairment should affect ATP-consuming reactions, including GSH synthesis, also contributing to the lowering of GSH inside the cell. Lowering of intracellular GSH concentration posseses dramatic consequences for cellular well-living and also should promote a loss of microcystin detoxification capacity. As shown by Pflugmacher et al. (1998), the glutathione-S-transferase (GST) enzyme catalyzes the conjugation of MICs with glutathione in several aquatic organisms. Metcalf et al. (2000) showed that the conjugate of the LR form of microcystin (MICLR) and MIC-YR with both cysteine and GSH is lesser toxic than MICs alone (in about 3-10 times). So it confirms the statement of Pflugmacher et al. (1998) that the conjugation catalyzed by GST is the first step for detoxification.

Besides the loss of detoxification capability, the alteration in GSH concentration can also have effects in several signaling pathways that are modulated by alterations in the redox status of the cell. Dickinson and Forman (2002) hypothesized that many environmental agents exert their deleterious effects by altering, either directly or indirectly, the cellular redox status through manipulation of thiols metabolism such as glutathione.

Table 2

Predicted phosphorylation sites in antioxidant enzymes in the aquatic model zebrafish (Danio rerio, Cyprinidae).

\begin{tabular}{|c|c|c|c|c|c|}
\hline Protein & $\begin{array}{l}\text { NCBI or GenBank } \\
\text { accession number }\end{array}$ & $\begin{array}{l}\text { Predicted phosphorylation sites } \\
\text { in zebrafish sequences }\end{array}$ & $\begin{array}{l}\text { Experimental evidences } \\
\text { (biological model) }\end{array}$ & $\begin{array}{l}\text { Reported phosphorylation } \\
\text { effect }\end{array}$ & References \\
\hline $\begin{array}{l}\text { Superoxide dismutase } \\
\text { (soluble) }\end{array}$ & NP_571369 (NCBI) & $\begin{array}{l}S \text { at position } 60 \\
T \text { at position } 40\end{array}$ & $\begin{array}{l}\text { Phosphorylation by ERK- } 1 \\
\text { (NFS-60 myeloid murine cells) }\end{array}$ & Unknown & Csar et al. (2001) \\
\hline $\begin{array}{l}\text { Glutamate cysteine ligase } \\
\text { (catalytic subunit) }\end{array}$ & NP_954971 (NCBI) & $\begin{array}{l}\text { S at positions } 132,172,259,292, \\
304,317,328,332,338,382,419 \\
455,465,571 \text { and } 595 \\
\text { T at positions } 15,105,113,163 \\
188,213 \text { and } 350 \\
\text { Y at positions } 53,100,238,265 \text {, } \\
330,336,344,442 \text { and } 591\end{array}$ & $\begin{array}{l}\text { Phosphorylation at S and T by } \\
\text { PKA, PKC (Sprague-Dawley rats) }\end{array}$ & $\begin{array}{l}\text { Reduction of } V \max \text {, with no } \\
\text { modification of } \mathrm{Km} \text { (male } \\
\text { Drosophila melanogaster and } \\
\text { C57BL/6 mice) }\end{array}$ & Toroser et al. (2006) \\
\hline Thioredoxin reductase & AA065267 (GenBank) & $\begin{array}{l}\text { S at positions } 15 \text { and } 106 \\
\mathrm{~T} \text { at positions } 34 \text { and } 166 \\
\mathrm{Y} \text { at positions } 30,114,139,154 \\
\text { and } 187\end{array}$ & None & Unknown & - \\
\hline Glutathione peroxidase & AA086703 (GenBank) & $\begin{array}{l}\mathrm{S} \text { at positions } 45,123 \text { and } 161 \\
\mathrm{~T} \text { at positions } 33,38 \text { and } 166 \\
\mathrm{Y} \text { at positions } 37 \text { and } 79\end{array}$ & $\begin{array}{l}\text { Phosphorylation at Y } 96 \text { by } \\
\text { c-Abl e Arg (SH-SY5Y cells) }\end{array}$ & $\begin{array}{l}\text { Phosphorylation increases } \\
\text { GPx1 activity }\end{array}$ & Cao et al. (2003a) \\
\hline $\begin{array}{l}\text { Glutathione-S-transferase } \\
\text { (alpha-like) }\end{array}$ & NP_998559 (NCBI) & $\begin{array}{l}\text { S at positions } 18,122,152 \text { and } 200 \\
\mathrm{~T} \text { at positions } 36,112 \text { and } 213 \\
\mathrm{Y} \text { at position } 210\end{array}$ & None & Unknown & - \\
\hline $\begin{array}{l}\text { Glutathione-S-transferase } \\
\text { (mu) }\end{array}$ & NP_997841 (NCBI) & $\begin{array}{l}\text { S at positions } 124,125 \text { and } 138 \\
\text { T at positions } 26 \text { and } 205 \\
Y \text { at positions } 7,28,33,41,62 \\
\text { and } 126\end{array}$ & None & Unknown & - \\
\hline \multirow[t]{2}{*}{$\begin{array}{l}\text { Glutathione-S-transferase } \\
\text { (pi) }\end{array}$} & NP_571809 (NCBI) & $\begin{array}{l}\text { S at positions } 88,165,167,174 \text {, } \\
177 \text { and } 183\end{array}$ & $\begin{array}{l}\text { Phosphorylation at S42 and } \\
\text { S184 by PKA and PKC } \\
\text { (human glioma cells). }\end{array}$ & $\begin{array}{l}\text { Phosphorylation enhances } \\
\text { the metabolic function of } \\
\text { the GSTP1 protein. }\end{array}$ & Lo et al. (2004) \\
\hline & & $\mathrm{T}$ at position 114 & $\begin{array}{l}\text { Phosphorylation at Y7 and Y198 } \\
\text { (human glioma and breast } \\
\text { cancer cells) by epidermal } \\
\text { growth factor receptor (EGFR) }\end{array}$ & $\begin{array}{l}\text { Phosphorylation increased } \\
\text { GSTP1 catalytic efficience by } \\
\text { reducing 3.8-fold the } K m \\
\text { for EA (ethacrynic acid) }\end{array}$ & Okamura et al. (2009) \\
\hline
\end{tabular}


Some evidences suggest that GSH depletion could be also related to cellular MICs uptake. Usually, the paradigm of MICs-induced cellular toxicity considered that it was determined by the cell ability in taking up the toxin or, in other words, the presence of toxin carriers in cell membrane. As acute effects are observed in liver, almost all studies that analyzed MICs uptake were done in mammalian hepatocytes. Runnegar et al. (1995) showed that the MICs incorporation was inhibited by cholate, taurocholate and bromosulfophtalein, suggesting the participation of one or more of the multi-specific organic anion/bile acid transporters in MICs-induced toxicity. Furthermore, studies from Fischer et al. (2005) and Meier-Abt et al. (2007) showed that MICs transport into the cell is carrier-mediated, involving members of Organic Anion Transporting Polypeptides (animals: Oatps; human: OATPs), present both in mammals liver and brain (Fischer et al., 2005) and also described in a fish species liver
(Leucoraja erinacea) (Meier-Abt et al., 2007). Oatps/OATPs are a group of membrane carriers which mediate a multi-specific substrate uptake in various organs of vertebrate animal species (Hagenbuch and Meier, 2003). Interestingly, there are experimental evidences showing that the activity of Oatps/OATPs is modulated by phosphorylation (Miyazaki et al., 2004). Both inhibition by protein kinase C (PKC) phosphorylation in serine residues of the transporters molecules (Uwai et al., 1998; You et al., 2000; Guo and Klaassen, 2001; Wolff et al., 2003) and stimulation by epidermal growth factor (EGF) via mitogen-actived protein kinases (MAPKs) (Sauvant et al., 2004) were already demonstrated, suggesting that the hyperphosphorylation state induced by MICs incorporation into the cell can alter, in some way, the activity of Oatps/OATPs.

The driving force for OATPs-mediated transport has not been investigated in detail for all transporters, but for Oatp1 and Oatp2,

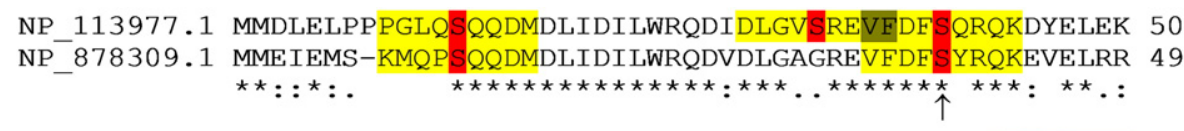

NP_113977.1 QKKLEKERQEQLQKEQEKAFFAQLQLDEETGEFLP-IQPAQHIQTDTSG- 98 NP 878309.1 RREQEEQELQERLQEQEKTLLAQLQLDEETGEFLPRSTPLTHTPEADGGG 99

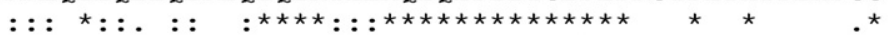

NP_113977.1 --SVSYSQVAHIPKQDALYFEDCMQLLAETFPFVDDHESLALDIPSHVES 146 NP_878309.1 AGEITQNGAFAEQEADPMSSFDEMQLLAETFPLTEPAES----APPCLNT 145

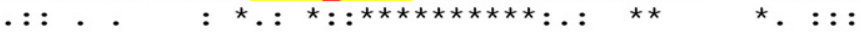

NP_113977.1 SVFTTPDQAQSLDSSLETAMTDLSSIQQDMEQVWQELFSIPELQ-CLNTE 195 NP_878309.1 SAPPSTDLMMPAD---VPAFTQNPLLPGSLDQAWMELLSLPELQQCLNMP 192

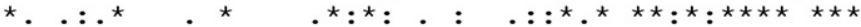

NP 113977.1 NKQQAETTTVPSPEATLTEMDSNYHFYSSIPSLEKEVDSCSPHFLHGFED 245 NP_878309.1 MQETLDMNAFMKPSTEAPTQNYSQYLPGMDHLGSAQTEVCPPEFTNTYNR 242

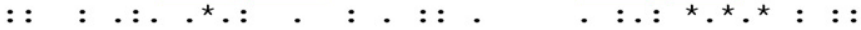

NP 113977.1 SFSSILSTDDASOLNSLLDSNPTLNTDFG-DEFYSAFLAEPSGGGSMPSSA 294 NP 878309.1 SFNTMVSPN-MNQL-SLN-VPDVGAEFGPEEFNELFYPEMEVKVNNPP-- 287

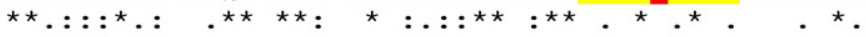

NP 113977.1 AISQSLSELLGG-PIEGCDLSLCK--AFNQKHTEGTVEFNDSDSGISLNT 341 NP_878309.1 -ITSDGGNMVGDPPVNPIDLQSFSPGDFSSGKPDPIVEFQDSDSGLSLDA 336

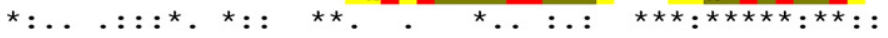

NP_113977.1 SPSRASPEHSVESSIYGDPPPGESDSEMEELDSAPGSVKQNGPKAQPTHS 391 NP_878309.1 SPHMSSPGKSITE--DGGFGFSDSDEEMEGSPGSMESDYNEIFPLVY 382

NP_113977.1 SGDTVQPLSPAQGHSAAVHESQCENTTKKEVPVSPGHQKVPFTKDKHSSR 441 NP ${ }^{-} 878309.1$ LNDGSQ--TPLSEKSSTEKQEMKLKNPKMEPAEASGHSKPPFTKDKLKKR 430

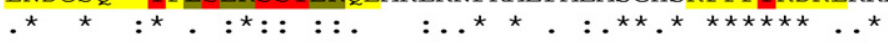

NP_113977.1 LEAHLTRDELRAKALHIPFPVEKIINLPVDDFNEMMSKEQFNEAQLALIR 491 NP-878309.1 SEARLSRDEQRAKALQIPFTVDMI INLPVDDFNEMMSKHQLNEAQLALVR 480

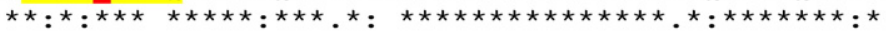

NP 113977.1 DIRRRGKNKVAAQNCRKRKLENIVELEQDLGHLKDEREKLLREKGENDRN 541 NP_878309.1 DIRRRGKNKVAAQNCRKRKLENIVGLEYELDSLKEEKERLMKEKSERSSN 530

NP 113977.1 LHLLKRKLSTLYLEVFSMLRDEDGKPYSPSEYSLQQTRDGNVFLVPKSKK 591 NP_878309.1 LKEMKQQLSTLYQEVFGMLRDENGKAFSPNEFSLQHTADGTVFLVPRLKK 580

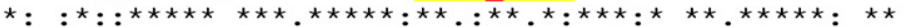

NP 113977.1 PDTKKN 597

NP_878309.1 TLVKNI 586

. . ${ }^{\star}$ :

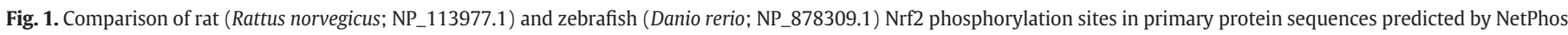

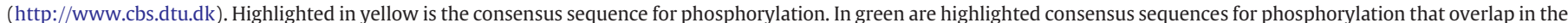

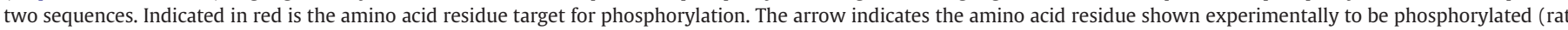

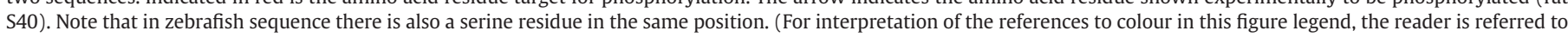
the web version of this article.) 
described by Fischer et al. (2005) to be involved in MICs uptake, exist experimental evidence indicating that intracellular GSH plays an important role (Hagenbuch and Meier, 2003). Thus, other possible cause of GSH depletion due to MICs exposure could be its exchange with the toxin. From this point of view, the simple entrance of MICs in the cells triggers the efflux of GSH through the same transport system, a mechanism useful for the toxin, since not only its entrance is allowed, but also the capacity of the cell to perform the detoxification reaction through GST activity is lowered because of the GSH efflux.

\section{How microcystins induce oxidative stress in aquatic organisms?}

Several hypotheses can be postulated at present about the "how" issue. Some of them are probably related to the link between the hyperphosphorylation state of the cell after MICs exposure and how it can affect the antioxidant system. Although some researchers have stated that antioxidant enzymes are mainly regulated at transcriptional level (Gehringer et al., 2004), increasing evidences are suggesting that post-transcriptional modifications can also modulate the activity of antioxidant enzymes (Rhee et al., 2005). A search of phosphorylation sites of important antioxidant defenses was performed by using NetPhos, version 2.0 (http://www.cbs.dtu.dk) (Blom et al., 1999), a kinase-specific prediction tool of protein phosphorylation sites. This computer tool was used on protein primary sequences of the zebrafish (Danio rerio, Cyprinidae), a well-known model of aquatic organism. As shown in Table 2, several possible phosphorylation sites do exist in the antioxidant system of zebrafish. Under this scenario two points should be considered: (1) the reliability of NetPhos prediction and (2) the effects of phosphorylation in antioxidants enzymes activities. The comparison of the data found in NetPhos with experimental evidences reported in literature for different biological models shows the considerable precision of the computer tool. For example, Huang et al. (2002) experimentally demonstrated the phosphorylation of Ser 40 of the transcriptional factor Nrf-2 from rats by PKC. Kwak et al. (2004) showed that phosphorylation induce an increase in mean life of rat Nrf2, a transcription factor involved in the expression of a number of antioxidant and phase II detoxifying enzymes (Kobayashi et al., 2009). Applying the NetPhos to the Nrf- 2 sequence from rat used by Huang et al. (2002) (NP_113977.1; NCBI), among several other possible sites, Ser 40 appears as a predicted one for phosphorylation with a high score (0.919). Interestingly, the alignment of zebrafish Nrf-2 sequence (NP_878309.1; NCBI) with the rat Nrf-2 sequence indicates similar phosphorylation sites, including the same site experimentally demonstrated in rat (Ser 40) that is also a phosphorylation target in zebrafish, as shown in NetPhos prediction (Fig. 1).
The same kind of comparison was done using sequences of zebrafish and human peroxiredoxin 1 (Prx1). Peroxiredoxins are a family of peroxidases that reduce $\mathrm{H}_{2} \mathrm{O}_{2}$ and alkyl hydroperoxides to water and alcohol, respectively, with the use of reducing equivalents provided by thiol-containing proteins (Hofmann et al., 2002). Chang et al. (2002) found that phosphorylation of Prx 1 on Thr90 by CDKs reduced the peroxidase activity of this protein by $80 \%$ in HeLa cells. The analysis of human Prx1 sequence (NP_859048.1; NCBI) in NetPhos also predicted this threonine residue as a site for phosphorylation with a high score (0.966). The analysis of zebrafish Prx1 (CAP09310.1; GenBank) sequence in NetPhos shows that Thr89 has a high score for phosphorylation (0.976). When the two sequences were aligned, it became evident that Thr90 of human sequence corresponds to Thr89 of zebrafish sequence, thus confirming similarities in the phosphorylation sites in the rat and zebrafish models (Fig. 2). From these data, it is possible that MICs exposure in aquatic organisms can augment the mean life of Nrf2 (triggering an antioxidant response) and diminish the peroxidase activity through phosphorylation of Prx1.

Besides the prediction indicated by NetPhos for several phosphorylation sites in different antioxidant enzymes (Table 2), experimental evidences also indicate that these enzymes are subjected to posttranscriptional regulation, i.e., phosphorylation. Sun et al. (1996) and Toroser et al. (2006) showed that phosphorylation of catalytic subunit of glutamate cysteine ligase (GLC), triggered by PKA and PKC, affected the enzymatic activity, mainly by lowering Vmax. GCL activity is the rate-limiting step in the de novo synthesis of GSH and its expression can be modulated by a number of different factors, including GSH depleting agents, reactive oxygen and nitrogen species, cytokines, and hormones (White et al., 2003). Gehringer et al. (2004) demonstrated that GCL transcription was induced $8 \mathrm{~h}$ after a single dose (75\% LD) of MICs i.p. injection in rats, what contributed to the returning of GSH concentration to the control levels 24 h post MICs exposure. The same study indicated that GST and glutathione peroxidase (GPx) presented transcriptional increases after MICs exposure, responses that should contribute to cellular detoxification.

If we consider that MICs induce a cellular hyperphosphorylation state, the results found by Gehringer et al. (2004) are in agreement with Kwak et al. (2004) who described an increase in GCL, GST and GPX expression when the transcription factor Nrf2 presented an augmented mean life after phosphorylation. However, the same cellular hyperphosphorylation state would lead to the phosphorylation of the new transcripted GCL, reducing its efficiency in promoting GSH synthesis (Sun et al., 1996; Toroser et al., 2006). For GST and GPx, there are experimental evidence that phosphorylation increases its activities (Lo et al., 2004; Okamura et al., 2009; Cao et al., 2003a,b). Yet

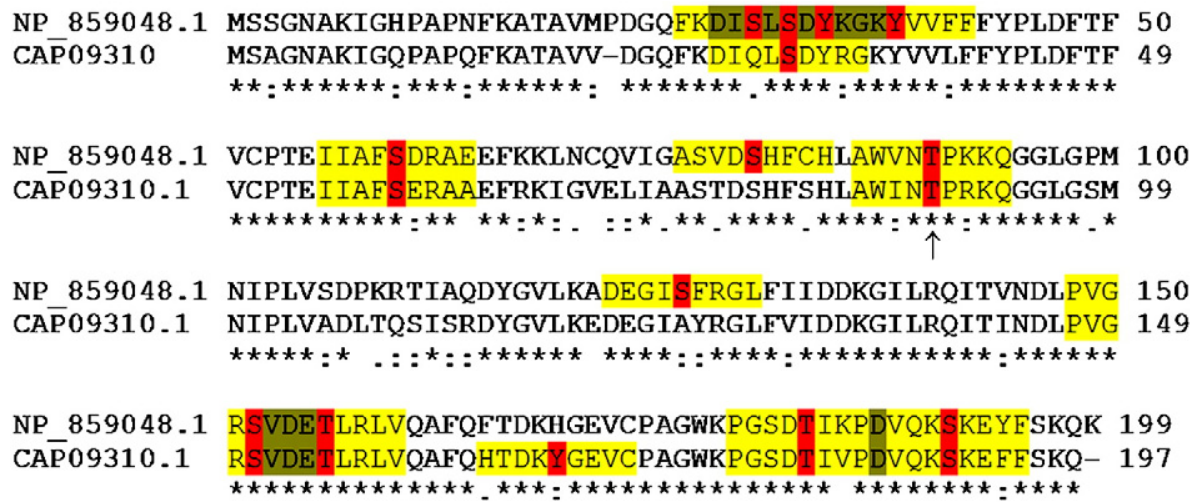

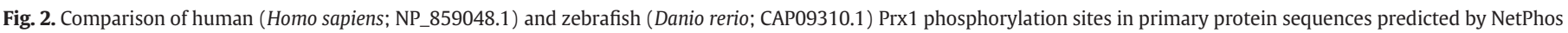

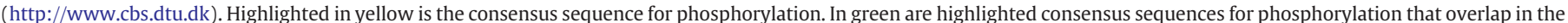

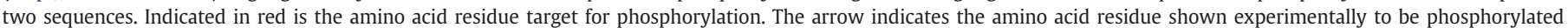

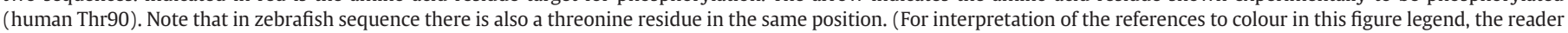
is referred to the web version of this article.) 
both enzymes need GSH as substrate. Therefore, besides all other MICs toxic effects described, it could be summed up the futile expense of ATP in the synthesis of proteins that probably do not have the optimum cellular concentration of its co-susbtrate GSH. Moreover, it should be remembered that another via of ATP stores depletion in MICs exposed cells could be through the mitochondrial damages exerted by this toxin (see Section 2), that can lead exposed cells to energy failure. In fact, Zhang et al. (2007) demonstrated that fish lymphocytes incubated with MIC-LR had ATP content depleted with the increasing of exposure time. In this study, after $4 \mathrm{~h}$ of incubation with MIC-LR (10 nM) ATP content decreased about 50\%.

\section{Chemoprevention strategies against oxidative stress generated by microcystins}

As MICs generate oxidative stress mainly by inducing an increase in ROS production associated with a depletion of antioxidant defenses, a chemical which is capable to induce an increase in antioxidant molecules synthesis could provide protection of organisms exposed to this toxin. A potential useful molecule, lipoic acid (LA) and its reduced form, dihydrolipoic acid (DHLA), seems to fulfill several criteria that an antioxidant must possess: they are ROS scavengers, they have metalchelating activity, participate in the recycle of other antioxidants and in the repair of damaged molecules induced by oxidative stress (Packer et al., 1995). Also, the redox potential of DHLA/LA (E0' $=-0.32 \mathrm{~V})$ is more negative than that of the reduced/oxidised glutathione (GSH/GSSG) and cysteine/cystine $(\mathrm{CSH} / \mathrm{CSSC})$ couples $\left(\mathrm{EO}^{\prime}=-0.24 \mathrm{~V}\right.$ and $-0.22 \mathrm{~V}$, respectively) (Hermes-Lima, 2004). Due to its redox potential, the pair
DHLA/LA can reduce CSSC to CSH and GSSG to GSH and in this last case, could be an alternate system to glutathione reductase activity. Previous studies have shown that LA ameliorates the toxic effects of compounds like arsenic in terms of brain lipid peroxidation (Shila et al., 2005).

Furthermore, valuable features of lipoic acid may be related to the transcription factor Nrf2 which, as previously mentioned, controls the expression of genes that are important to the antioxidant defense system (Kwak et al., 2004; Lee and Surh, 2005). The migration of transcription factors like Nrf2 from the cytoplasm to nucleus is the key process for the expression of important genes to the antioxidant defense, including those coding for the catalytic subunit of GCL and several GST isoenzymes (Lee and Surh, 2005). Authors as Suh et al. (2004) clearly showed that rats exposed to LA augmented the nuclear concentration of Nrf2 factor, promoting higher proteins levels of the catalytic subunit of GCL. In fish species, the study of Monserrat et al. (2008) reported that adding LA in a commercial diet reduced protein oxidation in liver and muscle, and augmented GCL activity in brain and liver.

Chemopreventive strategies must be also considered from a more ecotoxicological point of view. In a natural condition, intoxication by cyanobacteria is not necessarily only due to toxic effects of MICs. Several findings indicate that cyanobacterial blooms contain as-yetunidentified compounds and other known components that can evoke more pronounced toxic effects than MICs or other well recognized toxins (Oberemm et al., 1997, 1999; Pietsch et al., 2001; Burýsková et al., 2006). Burýsková et al. (2006) exposed Xenopus laevis embryos to five different fractions of complex cyanobacterial blooms. Fractions containing complex biomass or aqueous extract

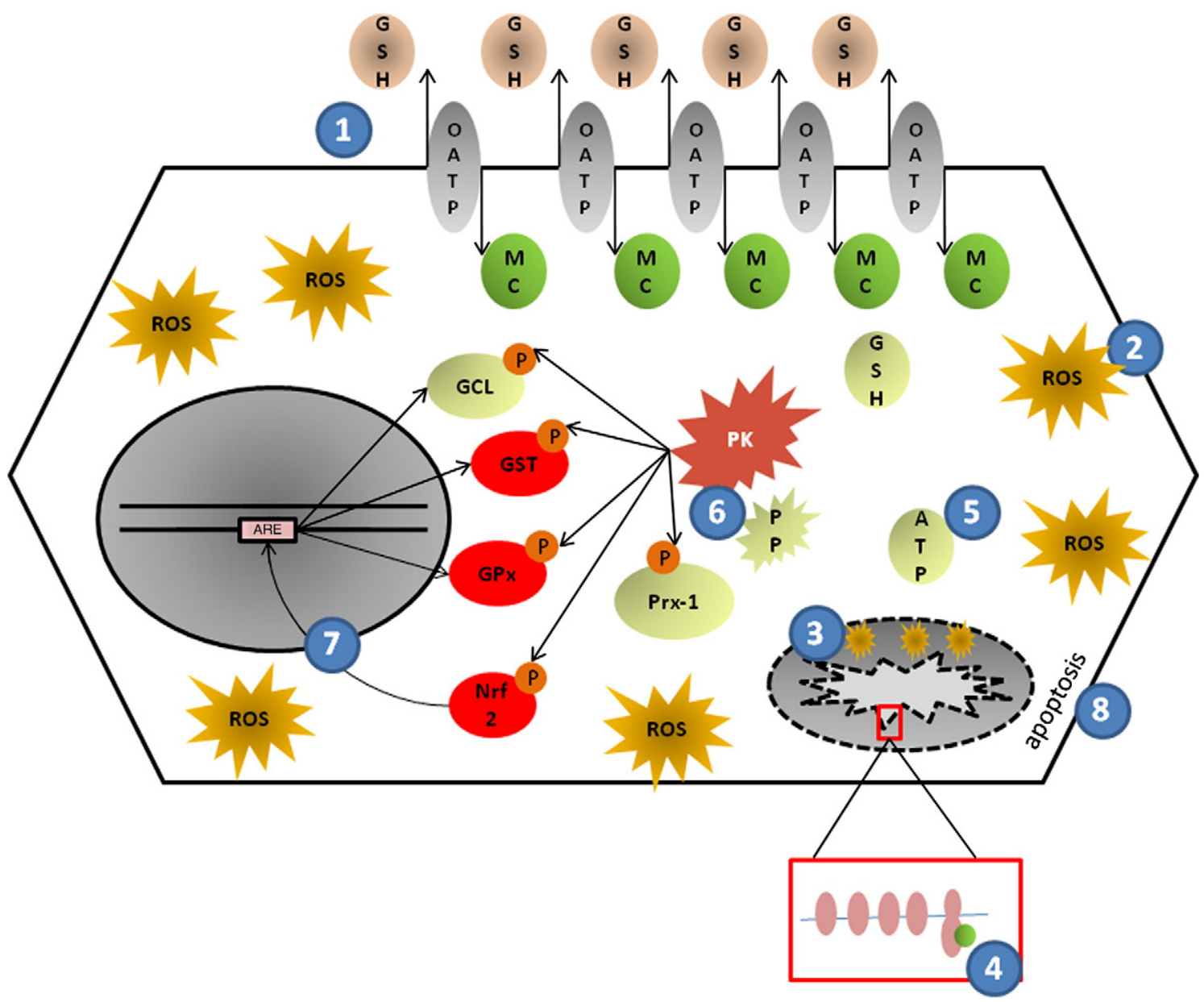

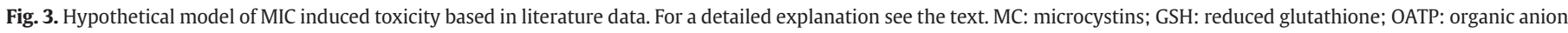

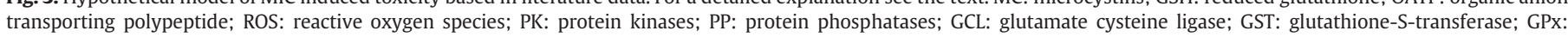
glutathione peroxidase; Nrf-2: NF-E2-related factor-2; ARE: antioxidant responsive element. 
were generally more toxic in terms of embryos mortality and growth inhibition whereas eluates, containing MICs were generally less toxic. Also, MICs had no significant effect on glutathione pool and enzymatic activity of GPx, GST and GR. These results indicate that MICs are not the only or major toxic component in complex cyanobacterial samples. In fact, Best et al. (2002) demonstrated that lipopolyssacharides (LPS) of cyanobacteria and heterotrophic bacteria that can be associated to cyanobacterial blooms, can reduce GST activity. This effect could have implications for both animal and human health, as GSTs participate not only in the MICs detoxication pathway (Pflugmacher et al., 1998) but also in the in vivo metabolism and detoxication of numerous other toxic compounds.

\section{Conclusions}

In light of literature data and hypothesis discussed herein, we suggest some important events (Fig. 3) that could occur in MICs intoxication and still need experimental corroboration:

1. MICs are incorporated into the cell via OATPs which uses GSH as driving force for the exchange with MICs. In this way, MICs incorporation per se could induce loss of intracellular GSH reducing the detoxification capability of the cell;

2. As GSH is the first line of defense against ROS, its cell efflux should increase ROS generation.

3. As mitochondrion depends on cytoplasmatic GSH, the depletion of cytosol GSH should reflect in a decreased GSH concentration inside mitochondria, a situation that favors ROS production and ETC disruption. Oxidative stress through oxidation of intracellular GSH favors the PTP opening, leading to membrane potential depolarization and mitochondrial permeability transition (MPT);

4. MICs can bind to the beta subunit of ATP-synthase, what could reduce ATP synthesis and contribute to the intensification of the mitochondrial membrane depolarization, disruption of ETC and ROS generation;

5. Mitochondrial disruption leads to an impairment of ATP production, affecting all cellular process that depend on ATP, such as de novo GSH synthesis;

6. Besides all this effects MICs inhibit protein phosphatases, leading to a cellular hyperphosphorylation state;

7. Hyperphosphorylation state together with the pro-oxidative environment inside the cell should favor the Nrf2 migration to the nuclei, promoting the transcription of genes involved in antioxidant response, such as GST, GPX and GCL. Phosphorylation and ATP depletion inhibits GCL activity, favoring the continuous depletion of GSH; phosphorylation activates GST and GPx, but the low GSH concentration limits their activities impairing even more cellular detoxification for MICs and $\mathrm{H}_{2} \mathrm{O}_{2}$. Finally, Prx inhibition by phosphorylation contributes to the lowering of ROS detoxification capability;

8. All these events together cause alteration in redox status of the cell and mitochondrial disruption what could lead to the release of cytochrome $c$ which, in turn, activates signaling cascades to apoptosis.

\section{References}

Amado LL, Garcia ML, Ramos PB, Freitas RF, Zafalon B, Ferreira JLR, et al. A method to measure total antioxidant capacity against peroxyl radicals in aquatic organisms: application to evaluate microcystins toxicity. Sci Total Environ 2009;407:2115-23.

Amorim Á, Vasconcelos V. Dynamics of microcystins in the mussel Mytilus galloprovincialis. Toxicon 1999;37:1041-52.

Aon MA, Cortassa S, Maack C, O'Rourke B. Sequential opening of mitochondrial ion channels as a function of glutathione redox thiol status. J Biol Chem 2007;282:21889-900.

Atencio L, Moreno I, Jos A, Pichardo S, Moyano R, Blanco A, et al. Dose-dependent antioxidant responses and pathological changes in tenca (Tinca tinca) after acute oral exposure to Microcystis under laboratory conditions. Toxicon 2008;52:1-12.

Baganz D, Staaks G, Pflugmacher S, Steinberg CEW. Comparative study of microcystinLR-induced behavioral changes of two fish species, Danio rerio and Leucaspius delineatus. Environ Toxicol 2004;19:564-70.
Best JH, Eddy FB, Codd GA. Effects of purified microcystin-LR and cell extracts of Microcystis strains PCC 7813 and CYA 43 on cardiac function in brown trout (Salmo trutta) alevins. Fish Physiol Biochem 2001;24:171-8.

Best JH, Pflugmacher S, Wiegand C, Eddy FB, Metcalf JS, Codd GA. Effects of enteric bacterial and cyanobacterial lipopolysaccharides, and of microcystin-LR, on glutathione S-transferase activities in zebra fish (Danio rerio). Aquat Toxicol 2002;60:223-31.

Bláha L, Kopp R, Imková K, Mares J. Oxidative stress biomarkers are modulated in silver carp (Hypophthalmichthys molitrix Val.) exposed to microcystin-producing cyanobacterial water bloom. Acta vet Brno 2004;73:477-82.

Blom N, Gammeltoft S, Brunak S. Sequence- and structure-based prediction of eukaryotic protein phosphorylation sites. J Mol Biol 1999;294:1351-62.

Bury NR, Eddy FB, Codd GA. The effects of the cyanobacterium Microcystis aeruginosa, the cyanobacterial hepatotoxin microcystin-LR, and ammonia on growth rate and ionic regulation of brown trout. J Fish Biol 1995;46:1042-54.

Bury NR, Flik G, Eddy FB, Codd GA. The effects of cyanobacteria and the cyanobacterial toxin microcystin-LR on $\mathrm{Ca}^{2+}$ transport and $\mathrm{Na}^{+} / \mathrm{K}^{+}$ATPase in tilapia gills. J Exp Biol 1996;199:1319-26.

Burýsková B, Hilscherová K, Babica P, Vrsková D, Marsálek B, Bláha L. Toxicity of complex cyanobacterial samples and their fractions in Xenopus laevis embryos and the role of microcystins. Aquat Toxicol 2006;80:346-54.

Cao C, Leng Y, Huang W, Liu X, Kufe D. Glutathione peroxidase 1 is regulated by the c-abl and arg tyrosine kinases. J Biol Chem 2003a;278:39609-14.

Cao C, Leng Y, Kufe D. Catalase activity is regulated by c-abl and arg in the oxidative stress response. J Biol Chem 2003b;278:29667-75.

Carmichael W. A world overview - one-hundred twenty-seven years of research on toxic cyanobacteria - where do we go from here? In: Kenneth Hudnell $\mathrm{H}$, editor. Proceedings of the interagency, international symposium on cyanobacterial harmful algal bloomsAdvances in Experimental Medicine and Biology; 2007. p. 95-115.

Cazenave J, Wunderlin DA, Bistoni MdlÁ, Amé MV, Krause E, Pflugmacher S, et al. Uptake, tissue distribution and accumulation of microcystin-RR in Corydoras paleatus, Jenynsia multidentata and Odontesthes bonariensis: a field and laboratory study. Aquat Toxicol 2005;75:178-90.

Cazenave J, Bistoni MdlA, Zwirnmann E, Wunderlin DA, Wiegand C. Attenuating effects of natural organic matter on microcystin toxicity in zebra fish (Danio rerio) embryos benefits and costs of microcystin detoxication. Environ Toxicol 2006a;21:22-32.

Cazenave J, Bistoni MdlA, Pesce SF, Wunderlin DA. Differential detoxification and antioxidant response in diverse organs of Corydoras paleatus experimentally exposed to microcystin-RR. Aquat Toxicol 2006b;76:1-12.

Cazenave J, Nores ML, Miceli M, Díaz MP, Wunderlin DA, Bistoni MA. Changes in the swimming activity and the glutathione S-transferase activity of Jenynsia multidentata fed with microcystin-RR. Water Res 2008;42:1299-307.

Chang T-S, Jeong W, Choi SY, Yu S, Kang SW, Rhee SG. Regulation of peroxiredoxin 1 activity by cdc2-mediated phosphorylation. J Biol Chem 2002;277:25370-6.

Chen J, Xie P. Tissue distributions and seasonal dynamics of the hepatotoxic microcystinsLR and -RR in two freshwater shrimps, Palaemon modestus and Macrobrachium nipponensis, from a large shallow, eutrophic lake of the subtropical China. Toxicon 2005;45:615-25.

Chen J, Xie P, Zhang D, Ke Z, Yang H. In situ studies on the bioaccumulation of microcystins in the phytoplanktivorous silver carp (Hypophthalmichthys molitrix) stocked in Lake Taihu with dense toxic Microcystis blooms. Aquaculture 2006a;261: 1026-38.

Chen Y-M, Lee T-H, Lee S-J, Huang H-B, Huang R, Chou H-N. Comparison of protein phosphatase inhibition activities and mouse toxicities of microcystins. Toxicon 2006b;47:742-6.

Chen J, Zhang D, Xie P, Wang Q, Ma Z. Simultaneous determination of microcystin contaminations in various vertebrates (fish, turtle, duck and water bird) from a large eutrophic Chinese lake, Lake Taihu, with toxic Microcystis blooms. Sci Total Environ 2009;407:3317-22.

Chernyak BV. Redox, regulation of the mitochondrial permeability transition pore. Biosci Rep 1997;17:293-302.

Chorus I, Bartram J. Toxic cyanobacteria in water: a guide to public health significance, monitoring and management. London: WHO, E and FN Spon/Chapman and Hall; 1999. $416 \mathrm{pp}$.

Contardo-Jara V, Pflugmacher S, Wiegand C. Multi-xenobiotic-resistance a possible explanation for the insensitivity of bivalves towards cyanobacterial toxins. Toxicon 2008;52:936-43.

Csar XF, Wilson NJ, Strike P, Sparrow L, McMahon KA, Ward AC, et al. Copper/zinc superoxide dismutase is phosphorylated and modulated specifically by granulocyte-colony stimulating factor in myeloid cells. Proteomics 2001;1:435-43.

Dawson RM. The toxicology of microcystins. Toxicon 1998;36:953-62.

de Figueiredo DR, Azeiteiro UM, Esteves SM, Gonçalves FJM, Pereira MJ. Microcystinproducing blooms - a serious global public health issue. Ecotoxicol Environ Saf 2004;59:151-63.

DeMott W, Dhawale S. Inhibition of in vitro protein phosphatase activity in three zooplankton species by microcystin-LR, a toxin from cyanobacteria. Arch Hydrobiol 1995;34:417-24

Dewes LJ, Sandrini JZ, Monserrat JM, Yunes JS. Biochemical and physiological responses after exposure to microcystins in the crab Chasmagnathus granulates (Decapoda, Brachyura). Ecotoxicol Environ Saf 2006;65:201-8.

Dickinson DA, Forman HJ. Cellular glutathione and thiols metabolism. Biochem Pharmacol 2002;64:1019-26.

Ding W-X, Ong CN. Role of oxidative stress and mitochondrial changes in cyanobacteriainduced apoptosis and hepatotoxicity. FEMS Microbiol Lett 2003;220:1-7.

Ding $\mathrm{W}-\mathrm{X}$, Shen H-M, Ong C-N. Critical role of reactive oxygen species and mitochondrial permeability transition in microcystin-induced rapid apoptosis in rat hepatocytes. Hepatology 2000a;32:547-55. 
Ding W-X, Shen HM, Ong C-N. Microcystic cyanobacteria extract induces cytoskeletal disruption and intracellular glutathione alteration in hepatocytes. Environ Health Perspect 2000b;108:605-9.

Ding $\mathrm{W}-\mathrm{X}$, Shen H-M, Ong C-N. Critical role of reactive oxygen species formation in microcystin-induced cytoskeleton disruption in primary cultured hepatocytes. J Toxicol Environ Health 2001;64:507-19.

Ding W-X, Shen H-M, Ong C-N. Calpain activation after mitochondrial permeability transition in microcystin-induced cell death in rat hepatocytes. Biochem Biophys Res Commun 2002;291:321-31.

Eriksson JE, Meriluoto JAO, Lindholm T. Accumulation of a peptide toxin from the cyanobacterium Oscillatoria agardhii in the freshwater mussel Anadonta cygnea. Hydrobiologia 1989;183:211-6.

Fischer WJ, Dietrich DR. Toxicity of the cyanobacterial cyclic heptapeptide toxins microcystin-LR and -RR in early life-stages of the African clawed frog (Xenopus laevis). Aquat Toxicol 2000a;49:189-98.

Fischer WJ, Dietrich DR. Pathological and biochemical characterization of microcystininduced hepatopancreas and kidney damage in carp (Cyprinus carpio). Toxicol Appl Pharmacol 2000b;164:73-81.

Fischer WJ, Hitzfeld BC, Tencalla F, Eriksson JE, Mikhailov A, Dietrich DR. Microcystin-LR toxicodynamics, induced pathology, and immunohistochemical localization in livers of blue-green algae exposed rainbow trout (Oncorhynchus mykiss). Toxicol Sci 2000;54:365-73.

Fischer WJ, Altheimer S, Cattori V, Meier PJ, Dietrich DR, Hagenbuch B. Organic anion transporting polypeptides expressed in liver and brain mediate uptake of microcystin. Toxicol Appl Pharmacol 2005;203:257-63.

Gaete V, Canelo E, Lagos N, Zambrano F. Inhibitory effects of Microcystis aeruginosa toxin on ion pumps of the gill of freshwater fish. Toxicon 1994;32:121-7.

Gehringer MM, Shephard EG, Downing TG, Wiegand C, Neilan BA. An investigation into the detoxification of microcystin-LR by the glutathione pathway in Balb/c mice. Int J Biochem Cell Biol 2004;36:931-41.

Guo GL, Klaassen CD. Protein kinase C suppresses rat organic anion transporting polypeptide 1- and 2-mediated uptake. J Pharmacol Exp Ther 2001;299:551-7.

Hagenbuch B, Meier PJ. The superfamily of organic anion transporting polypeptides. Biochim Biophys Acta 2003;1609:1-18.

Halliwell B, Gutteridge JMC, editors. Free radicals in biology and medicine. Fourth ed. New York: Oxford University Press; 2007.

Heinze R. Toxicity of the cyanobacterial toxin microcystin-LR to rats after 28 days intake with the drinking water. Environ Toxicol 1999;14:57-60.

Hermes-Lima M. Oxygen in biology and biochemistry: role of free radicals. In: Storey KB, editor. Functional metabolism: regulation and adaptation. New York: John Wiley and Sons; 2004. p. 319-68.

Hernández JM, López-Rodas V, Costas E. Microcystins from tap water could be a risk factor for liver and colorectal cancer: a risk intensified by global change. Med Hypotheses 2009;72:539-40.

Hofmann B, Hecht HJ, Flohé L. Peroxiredoxins. Biol Chem. 2002;383:347-64.

$\mathrm{Hu}$ Z, Chen H, Pang C, Lin Q. The expression of p53 and p16 in the course of microcystinLR inducing of liver tumor. Chin Ger J Clin Oncol 2008;7:P690-3.

Huang H-C, Nguyen T, Pickett CB. Phosphorylation of Nrf2 at Ser-40 by protein kinase C regulates antioxidant response element-mediated transcription. J Biol Chem 2002;277:42769-74

Ibelings BW, Chorus I. Accumulation of cyanobacterial toxins in freshwater "seafood" and its consequences for public health: a review. Environ Pollut 2007;150:177-92.

Jones DP. Redefining oxidative stress. Antioxid Redox Signal 2006;8:1865-79.

Jos Á, Pichardo S, Prieto AI, Repetto G, Vázquez CM, Morenoa I, et al. Toxic cyanobacterial cells containing microcystins induce oxidative stress in exposed tilapia fish (Oreochromis sp.) under laboratory conditions. Aquat Toxicol 2005;72: 261-71.

Juhel G, Davenport J, O'Halloran J, Culloty S, Ramsay R, James K, et al. Pseudodiarrhoea in zebra mussels Dreissena polymorpha (Pallas) exposed to microcystins. J Exp Biol 2006;209:810-6

Kamjunke N, Mendonca R, Hardewig I, Mehner T. Assimilation of different cyanobacteria as food and the consequences for internal energy stores of juvenile roach. J Fish Biol 2002;60:731-8.

Kobayashi M, Li L, Iwamoto N, Nakajima-Takagi Y, Kaneko H, Nakayama Y, et al. The antioxidant defense system Keap1-Nrf2 comprises a multiple sensing mechanism for responding to a wide range of chemical compounds. Mol Cell Biol 2009;29:493-502.

Kwak M-K, Wakabayashi N, Kensler TW. Chemoprevention through the Keap1-Nrf2 signaling pathway by phase 2 enzyme inducers. Mutat Res 2004;555:133-48.

Leão JC, Geracitano LA, Monserrat JM, Amado LL, Yunes JS. Microcystin-induced oxidative stress in Laeonereis acuta (Polychaeta, Nereididae). Mar Environ Res 2008;66:92-4.

Lee J, Surh Y. Nrf2 as a novel molecular target for chemoprevention. Cancer Lett 2005;224:171-84.

Li X, Liu Y, Song L, Liu J. Responses of antioxidant systems in the hepatocytes of common carp (Cyprinus carpio L.) to the toxicity of microcystin-LR. Toxicon 2003;42:85-9.

Li X-Y, Chung I-K, Kim J-I, Lee J-A. Subchronic oral toxicity of microcystin in common carp (Cyprinus carpio L.) exposed to Microcystis under laboratory conditions. Toxicon 2004:44:821-7.

Li X-Y, Chung I-K, Kim J-I, Lee J-A. Oral exposure to Microcystis increases activityaugmented antioxidant enzymes in the liver of loach (Misgurnus mizolepis) and has no effect on lipid peroxidation. Comp Biochem Physiol C 2005;141:292-6.

Li D, Xie P, Zhang X. Changes in plasma thyroid hormones and cortisol levels in crucian carp (Carassius auratus) exposed to the extracted microcystins. Chemosphere 2008a;74:13-8.

Li G, Xie P, Fu J, Hao L, Xiong O Li H. Microcystin-induced variations in transcription of GSTs in an omnivorous freshwater fish, goldfish. Aquat Toxicol 2008b;88:75-80.
Li H, Xie P, Li G, Hao L, Xiong Q. In vivo study on the effects of microcystin extracts on the expression profiles of proto-oncogenes (c-fos, c-jun and c-myc) in liver kidney and testis of male Wistar rats injected i.v. with toxins. Toxicon 2009;53: 169-75.

Lo H-WL, Antoun GR, Ali-Osman F. The human glutathione S-transferase P1 protein is phosphorylated and its metabolic function enhanced by the Ser/Thr protein kinases, cAMP-dependent protein kinase and protein kinase $C$, in glioblastoma cells. Cancer Res 2004;64:9131-8.

Maher P. The effects of stress and aging on glutathione metabolism. Ageing Res Rev 2005; $4: 288-314$.

Malbrouck C, Kestemont P. Effects of microcystins on fish. Environ Toxicol Chem 2006;25:72-86.

Martins JC, Vasconcelos VM. Microcystin dynamics in aquatic organisms. J Toxico Environ Health 2009;12:65-82.

Meier-Abt F, Hammann-Hänni A, Stieger B, Ballatori N, Boyer JL. The organic anion transport polypeptide $1 \mathrm{~d} 1$ (Oatp1d1) mediates hepatocellular uptake of phalloidin and microcystin into skate liver. Toxicol Appl Pharmacol 2007;218:274-9.

Meister A. Mitochondrial changes associated with glutathione deficiency. Biochim Biophys Acta 1995;1271:35-42.

Metcalf JS, Beattie KA, Pflugmacher S, Codd GA. Immuno-crossreactivity and toxicity assessment of conjugation products of the cyanobacterial toxin, microcystin-LR FEMS Microbiol Lett 2000;189:155-8.

Mikhailov A, Härmälä-Braskén A-S, Hellman J, Meriluoto J, Eriksson JE. Identification of ATP-synthase as a novel intracellular target for microcystin-LR. Chem Biol Interact 2003;142:223-37.

Milutinovi A, Zivin M, Zorc-Pleskovic R, Sedmak B, Suputa D. Nephrotoxic effects of chronic administration of microcystins -LR and -YR. Toxicon 2003;42:281-8.

Miyazaki H, Sekine T, Endou $\mathrm{H}$. The multispecific organic anion transporter family: properties and pharmacological significance. Trends Pharmacol Sci 2004;25:654-62.

Mohamed ZA. Accumulation of cyanobacterial hepatotoxins by Daphnia in some Egyptian irrigation canals. Ecotoxicol Environ Saf 2001;50: 4-8.

Monserrat JM, Lima JV, Ferreira JLR, Acosta D, Garcia ML, Ramos PB, et al. Modulation of antioxidant and detoxification responses mediated by lipoic acid in the fish Corydoras paleatus (Callychthyidae). Comp Biochem Physiol C 2008;148:287-92.

Oberemm A, Fastner J, Steinberg CEW. Effects of microcystin-LR and cyanobacterial crude extracts on embryo-larval development of zebrafish (Danio rerio). Water Res $1997 ; 31: 2918-21$.

Oberemm A, Becker J, Codd GA, Steinberg C. Effects of cyanobacterial toxins and aqueous crude extracts of cyanobacteria on the development of fish and amphibians. Environ Toxicol 1999;14:77-88.

Okamura T, Singh S, Buolamwini J, Haystead TA, Friedman HS, Bigner DD, et al. Tyrosine phosphorylation of the human glutathione S-transferase p1 by epidermal growth factor receptor. J Biol Chem 2009;M808153200.

Packer L, Witt EH, Tritschler HJ. Alpha-lipoic acid as a biological antioxidant. Free Radic Biol Med 1995; 19:227-50.

Pflugmacher S, Wiegand C, Oberemm A, Beattie KA, Krause E, Codd GA, et al. Identification of an enzimatically formed glutathione conjugate of the cyanobacterial hepatoxin microcystin-LR: the first step of detoxication. Biochim Biophys Acta 1998;1425:527-33.

Pietsch C, Wiegand C, Amé MV, Nicklisch A, Wunderlin D, Pflugmacher S. The effects of a cyanobacterial crude extract on different aquatic organisms: evidence for cyanobacterial toxin modulating factors. Environ Toxicol 2001;16:535-42.

Pinho GLL, Moura da Rosa C, Yunes JS, Luquet CM, Bianchini A, Monserrat JM. Toxic effects of microcystins in the hepatopancreas of the estuarine crab Chasmagnathus granulatus (Decapoda, Grapsidae). Comp Biochem Physiol C 2003;135:459-68.

Pinho GLL, Moura da Rosa C, Maciel FE, Bianchini A, Yunes JS, Proença LAO, et al Antioxidant responses and oxidative stress after microcystin exposure in the hepatopancreas of an estuarine crab species. Ecotoxicol Environ Saf 2005;61:353-60.

Pires LMD, Kusserow R, Van Donk E. Influence of toxic and non-toxic phytoplankton on feeding and survival of Dreissena polymorpha (Pallas) larvae. Hydrobiologia 2003;491:193-200

Prieto AI, Jos A, Pichardo S, Moreno I, Cameán AM. Differential oxidative stress responses to microcystins $L R$ and $R R$ in intraperitoneally exposed tilapia fish (Oreochromis sp.). Aquat Toxicol 2006;77:314-21.

Prieto AI, Pichardo S, Jos Á, Moreno I, Cameán AM. Time-dependent oxidative stress responses after acute exposure to toxic cyanobacterial cells containing microcystins in tilapiafish (Oreochromis niloticus) under laboratory conditions. Aquat Toxicol 2007;84:337-45.

Qiu T, Xie P, Guo L, Zhang D. Plasma biochemical responses of the planktivorous filterfeeding silver carp (Hypophthalmichthys molitrix) and bighead carp (Aristichthys nobilis) to prolonged toxic cyanobacterial blooms in natural waters. Environ Toxicol Pharmacol 2009;27:350-6.

Rhee SG, Yang K-S, Kang SW, Woo HA, Chang T-S. Controlled elimination of intracellular $\mathrm{H}_{2} \mathrm{O}_{2}$ : regulation of peroxiredoxin, catalase, and glutathione peroxidase via posttranslational modification. Antioxid Redox Signal 2005;7:619-26.

Rosa CE, de Souza MS, Yunes JS, Proença LAO, Nery LEM, Monserrat JM. Cyanobacteria blooms in estuarine ecosystems: characteristics and effects on Laeonereis acuta (Polychaeta, Nereididae). Mar Pollut Bull 2005;50:956-64.

Runnegar MTC, Andrews J, Gerdes RG, Falconer IR. Injury to hepatocytes induced by a peptide toxin from the cyanobacterium Microcystis aeruginosa. Toxicon 1987;25:1235-9.

Runnegar M, Berndt N, Kaplowitz N. Microcystin uptake and inhibition of protein phosphatases: effects of chemoprotectants and self-inhibition in relation to known hepatic transporters. Toxicol Appl Pharmacol 1995;134:264-72.

Sauvant C, Hesse D, Holzinger H, Evans KK, Dantzler WH, Gekle M. Action of EGF and PGE2 on basolateral organic anion uptake in rabbit proximal renal tubules and 
hOAT1 expressed in human kidney epithelial cells. Am J Physiol Renal Physiol 2004;286:F774-83.

Seki H, Takahashi M, Hara Y, Ichimura S. Dynamics of dissolved oxygen during algal bloom in lake Kasumigaura, Japan. Water Res 1980;14:179-83.

Shila S, Kokilavani V, Subathra M, Panneerselvam C. Brain regional responses in antioxidant system to [alpha]-lipoic acid in arsenic intoxicated rat. Toxicology 2005;210:25-36.

Soares RM, Magalhães VF, Azevedo SMFO. Accumulation and depuration of microcystins (cyanobacteria hepatotoxins) in Tilapia rendalli (Cichlidae) under laboratory conditions. Aquat Toxicol 2004;70:1-10.

Suh JH, Shenvi SV, Dixon BM, Liu H, Jaiswal AK, Liu R-M, et al. Decline in transcriptiona activity of Nrf2 causes age-related loss of glutathione synthesis, which is reversible with lipoic acid. Proc Natl Acad Sci 2004;101:3381-6.

Sun W-M, Huang Z-Z, Lu SC. Regulation of $\gamma$-glutamylcysteine synthetase by protein phosphorylation. Biochem J 1996;320:321-8.

Svrcek C, Smith DW. Cyanobacteria toxins and the current state of knowledge on water treatment options: a review. J Environ Eng Sci 2004;3:155-85.

Toroser D, Yarian CS, Orr WC, Sohal RS. Mechanisms of $\gamma$-glutamylcysteine ligase regulation. Biochim Biophys Acta 2006;1760:233-44.

Uwai Y, Okuda M, Takami K, Hashimoto Y, Inui K-I. Functional characterization of the rat multispecific organic anion transporter OAT1 mediating basolateral uptake of anionic drugs in the kidney. FEBS Lett 1998;438:321-4.

Vinagre TM, Alciati JC, Regoli F, Bocchetti R, Yunes JS, Bianchini A, et al. Effect of hepatotoxins (microcystin) on ion-regulation and antioxidant system in gills of Chasmagnathus granulatus (Decapoda, Grapsidae). Comp Biochem Physiol C 2003;135:67-75.

Votto APS, Renon VP, Yunes JS, Rumjanek VM, Marques Capella MA, Moura Neto V, et al. Sensitivity to microcystins: a comparative study in human cell lines with and without multidrug resistance phenotype. Cell Biol Int 2007;31:1359-66.

White CC, Viernes H, Krejsa CM, Botta D, Kavanagh TJ. Fluorescence-based microtiter plate assay for glutamate-cysteine ligase activity. Anal Biochem 2003;318:175-80.

Wiegand C, Pflugmacher S. Ecotoxicological effects of selected cyanobacteria secondary metabolites a short review. Toxicol Appl Pharmacol 2005;203:201-18.

Wiegand C, Pflugmacher S, Oberemm A, Meems N, Beattie KA, Steinberg CEW, et al Uptake and effects of microcystin-LR on detoxication enzymes of early life stages of the zebra fish (Danio rerio). Environ Toxicol 1999;14:89-95.
Winston GW, Regoli F, Dugas Jr AJ, Fong JH, Blanchard KA. A rapid gas chromatographic assay for determining oxyradical scavenging capacity of antioxidants and biological fluids. Free Radic Biol Med 1998;24:480-93.

Wolff NA, Thies K, Kuhnke N, Reid G, Friedrich B, Lang F, et al. Protein kinase C activation downregulates human organic anion transporter 1-mediated transport through carrier internalization. J Am Soc Nephrol 2003;14:1959-68.

Xie L, Xie P, Ozawa K, Honma T, Yokoyama A, Park H-D. Dynamics of microcystins-LR and -RR in the phytoplanktivorous silver carp in a sub-chronic toxicity experiment. Environ Pollut 2004;127:431-9.

You G, Kuze K, Kohanski RA, Amsler K, Henderson S. Regulation of mOAT-mediated organic anion transport by okadaic acid and protein kinase C in LLC-PK1 cells. J Biol Chem 2000;275:10278-84.

Zegura B, Sedmak B, Filipic M. Microcystin-LR induces oxidative DNA damage in human hepatoma cell line HepG2. Toxicon 2003;41:41-8.

Zegura B, Zajc I, Lah TT, Filipic M. Patterns of microcystin-LR induced alteration of the expression of genes involved in response to DNA damage and apoptosis. Toxicon 2008;51:615-23.

Zhang J, Zhang H, Chen Y. Sensitive apoptosis induced by microcystins in the crucian carp (Carassius auratus) lymphocytes in vitro. Toxicol In Vitro 2006;20:560-6.

Zhang $\mathrm{H}$, Zhang J, Chen Y, Zhu Y. Influence of intracellular $\mathrm{Ca}^{2+}$, mitochondria membrane potential, reactive oxygen species, and intracellular ATP on the mechanism of microcystin-LR induced apoptosis in Carassius auratus lymphocytes in vitro. Environ Toxicol 2007;22:559-64.

Zhang H, Zhang J, Chen Y, Zhu Y. Microcystin-RR induces apoptosis in fish lymphocytes by generating reactive oxygen species and causing mitochondrial damage. Fish Physiol Biochem 2008;34:307-12.

Zhang D, Xie P, Liu Y, Qiu T. Transfer, distribution and bioaccumulation of microcystins in the aquatic food web in Lake Taihu, China, with potential risks to human health. Sci Total Environ 2009;407:2191-9.

Zhao M, Xie S, Zhu X, Yang Y, Gan N, Song L. Effect of dietary cyanobacteria on growth and accumulation of microcystins in Nile tilapia (Oreochromis niloticus). Aquaculture 2006;261:960-6. 